\title{
THE ZINGIBERIDAE, A NEW SUBCLASS OF LILIOPSIDA (MONOCOTYLEDONS)
}

\section{Arthur Cronquist}

\begin{abstract}
Cronquist, Arthur (New York Botanical Garden, Bronx, NY 10458). The Zingiberidae, a new subclass of Liliopsida (Monocotyledons). Brittonia 30: 505. 1978. -The Zingiberidae are described as a new subclass, containing the orders Zingiberales and Bromeliales.
\end{abstract}

In recent systems of classification of flowering plants, the Zingiberales and Bromeliales have usually been associated with either the Liliidae or the Commelinidae (under whatever names). The two orders are in fact anomalous in either subclass, and the definition of both subclasses is facilitated by their exclusion. In spite of their dissimilar aspect, the Zingiberales and Bromeliales share a number of features that are alien to one or another (or both) of the two larger groups to which they have been referred. Thus it is useful to establish a subclass to accommodate these two otherwise aberrant orders. The name Zingiberidae is already coming into use in taxonomic works that draw on my recent unpublished studies. Therefore it seems necessary to validate the name at this time, instead of deferring it to the larger work that is now in late manuscript.

The Zingiberidae, Commelinidae, and Liliidae may be characterized as follows:

Zingiberidae Cronquist, subclassis nov.

Flores hypogyni vel saepius epigyni, nectariis septalibus vel ovarium coronantibus e septalibus quasi ortis instructi; sepala a petalis manifeste diversa, saepe herbaceo viridia; endospermium (ut perispermium, si adsit) praesertim amylaceum, saepissime farinaceum ex amyli granulis compositum; stomata cellulis (2-) 4 vel numerosioribus suffulta; vasa saepissime in radicibus tantum, rarius etiam in caulibus foliisque incidentia.

Flowers hypogynous to much more often epigynous, with septal nectaries or with nectaries atop the ovary that appear to be derived from septal nectaries; sepals obviously differentiated from the petals, often green and herbaceous in texture; endosperm (and perisperm when present) largely starchy, very often mealy and with compound starch-grains; stomates with (2) 4 or more supporting cells; vessels most commonly confined to the roots, but sometimes present also in the shoot. Orders Zingiberales and Bromeliales. TYPE: Zingiberales.

Commelinidae Takhtajan 1966.

Flowers strictly hypogynous, usually without nectar, and never with septal nectaries; perianth with well differentiated sepals and petals, or reduced and chaffy or bristly or wanting; endosperm largely or wholly starchy, often mealy and with compound starch-grains; stomates mostly paracytic, rarely anomocytic or with more than 2 supporting cells; vessels usually present throughout the vegetative body. Orders Commelinales, Eriocaulales, Restionales, Juncales, Cyperales (including Poales), and Typhales.

\section{LiLiIDAE Takhtajan 1966.}

Flowers hypogynous or very often epigynous, usually with nectaries (often septal nectaries); sepals usually more or less petaloid; endosperm often wanting, when present typically very hard, with reserves of hemicelluose, protein, and oil, less often starchy but not mealy, the starch-grains solitary; stomates mostly anomyctic, seldom paracytic or tetracytic; vessels usually confined to the roots, but in a few families and scattered genera present also in the shoot. Orders Liliales and Orchidales.

BRItTonia 30: 505. October-December, 1978. 